\title{
Occult Hepatitis B Virus Infection among HIV Positive Patients in Nigeria
}

\section{Oluyinka Oladele Opaleye, ${ }^{1}$ Adeolu Sunday Oluremi, ${ }^{1}$ Adetona Babatunde Atiba, ${ }^{1}$ Moses Olubusuyi Adewumi, ${ }^{2}$ Olatunji Victor Mabayoje, ${ }^{3}$ Emmanuel Donbraye, ${ }^{4}$ Olusola Ojurongbe, ${ }^{1}$ and 0. Adekunle Olowe ${ }^{1}$}

\author{
${ }^{1}$ Department of Medical Microbiology and Parasitology, Ladoke Akintola University of Technology, Osogbo, Nigeria \\ ${ }^{2}$ Department of Virology, College of Medicine, University College Hospital, University of Ibadan, Ibadan, Nigeria \\ ${ }^{3}$ Department of Hematology, Ladoke Akintola University of Technology, Osogbo, Nigeria \\ ${ }^{4}$ Department of Medical Microbiology and Parasitology, College of Health Sciences, Obafemi Awolowo University, \\ PMB 4400, Ile-Ife, Nigeria
}

Correspondence should be addressed to Oluyinka Oladele Opaleye; yopaleye@yahoo.com

Received 27 January 2014; Accepted 28 March 2014; Published 24 April 2014

Academic Editor: Sukla Biswas

Copyright (C) 2014 Oluyinka Oladele Opaleye et al. This is an open access article distributed under the Creative Commons Attribution License, which permits unrestricted use, distribution, and reproduction in any medium, provided the original work is properly cited.

\begin{abstract}
HIV has been known to interfere with the natural history of hepatitis B virus (HBV) infection. In this study we investigate the prevalence of occult hepatitis B virus infection (OBI) among HIV-infected individuals in Nigeria. Overall, 1200 archived HIV positive samples were screened for detectable HBsAg using rapid technique, in Ikole Ekiti Specialist Hospital. The HBsAg negative samples were tested for $\mathrm{HBsAg}$, anti-HBc, and anti-HCV by ELISA. Polymerase chain reaction was used for HBV DNA amplification and CD4 counts were analyzed by cytometry. Nine hundred and eighty of the HIV samples were HBsAg negative. HBV DNA was detected in 21/188 (11.2\%) of patients without detectable HBsAg. CD4 count for the patients ranged from 2 to 2,140 cells $/ \mu \mathrm{L}$ of blood (mean $=490$ cells $/ \mu \mathrm{L}$ of blood). HCV coinfection was detected only in $3 / 188(1.6 \%)$ of the HIV-infected patients $(P>0.05)$. Twenty-eight $(29.2 \%)$ of the $96 \mathrm{HIV}$ samples screened were positive for anti-HBc. Averagely the HBV viral load was $<50$ copies/mL in the OBI samples examined by quantitative PCR. The prevalence of OBI was significantly high among HIV-infected patients. These findings highlight the significance of nucleic acid testing in HBV diagnosis in HIV patients.
\end{abstract}

\section{Introduction}

Hepatitis B virus (HBV) is a major health problem, with approximately 400 million chronically infected people worldwide, and $15-60 \%$ of the normal population in many African countries may be positive for one or more of the serological markers of hepatitis B virus infection [1]. These chronically infected patients not only are at an increased stage of developing liver cirrhosis and hepatocellular carcinoma, but also serve as a potential reservoir of infection [1]. The major structural protein of virus envelope, hepatitis B surface antigen (HBsAg), is universally considered as a diagnostic marker of HBV infection. The absence of HBsAg in the serum and the presence of antibodies to core antigen (anti-HBc) usually indicate resolved infection [2]. Occult HBV infection (OBI) usually has a serological evidence of previous HBV infection that has been described in a few cases [2].

HIV coinfection has been reported to modify the natural history of HBV with potential consequences on morbidity and mortality [3]. Data on OBI in ART untreated HIV patients is limited from a vast number of African countries like Nigeria, where prevalence of HBV monoinfection, mode of transmission, viral genotype, and mutational pattern varies considerably in different parts of the country. No previous study from Nigeria on prevalence on OBI among any groups has been carried out. This is particularly important as exposure to HBV is common among HIV-infected cases because of shared routes of transmission [4]. Notably, there is 
considerable variation in prevalence of $\mathrm{HIV} / \mathrm{HBV}$ coinfection according to geographic regions and exposure risk [5].

Successful implementation of ART leads to immune reconstitution that can potentially result in immune mediated liver injury in the setting of HBV coinfection. Some studies have reported an association between OBI and elevated transaminase [6]; therefore identification of $\mathrm{OBI}$ is of importance.

\section{Materials and Methods}

Of the 1,200 HIV-infected patients enrolled in the HAART Clinic of the Specialist Hospital, Ikole, Ekiti State, Nigeria, from October, 2012, to April, 2013, we identified $980 \mathrm{HBsAg}$ negative patients (ART-naïve subjects). Among them, 188 were selected for the study by a simple random method. Informed consent was obtained from the patients, and the institutional committee approved the study protocol. The sera were stored at $-20^{\circ} \mathrm{C}$ until tested. Ethical clearance was obtained from the Ethical Committee of the Ikole Ekiti Specialist Hospital.

2.1. Serological Testing. All samples were tested for HBsAg, anti-HBs, anti-HBc, anti-HCV, and anti-HIV using ELISA (DRG Diagnostics, Marburg, Germany). All anti-HBc positive samples were retested for HBsAg as well as for anti-HBc, and only repeat positive samples were included in the study.

2.2. DNA Extraction. DNA was extracted from all the serum samples using QIAamp DNA Blood Mini kit (Qiagen GmbH, Hilden, Germany) following the manufacturers' instructions. Briefly, samples $(200 \mu \mathrm{L})$ were incubated with protease and lysis buffer. After incubation, there were two washing steps, and the nucleic acids were eluted in a volume of $50 \mu \mathrm{L}$ of elution buffer. The eluted DNA was stored at $-20^{\circ} \mathrm{C}$ until tested.

2.3. Hepatitis B Virus Specific Nested PCR. The presence of HBV DNA was examined in all samples using a routine diagnostic PCR. Primer pairs were designed from the highly conserved overlapping regions of the $\mathrm{S}$ and $\mathrm{P}$ genes of the HBV genome. A nested PCR was performed: outer primer pairs were HBPr134 (sense) $5^{\prime}$-TGCTGCTATGCCTCATCTTC- $3^{\prime}$ and HBPr135 (antisense) $5^{\prime}$-CAGAGACAAAAGAAAATTGG $-3^{\prime}$ and the inner primer pairs were HBPr75 (sense) $5^{\prime}$-CAAGGTTATGTTGCCCGTTTGTCC-3' ${ }^{\prime}$ and HBPr94 (antisense) $5^{\prime}$-GGTATAAAGGGACTCACGATG$3^{\prime}$. PCR amplifications were carried out in $25 \mu \mathrm{L}$ reaction volumes with $5 \mathrm{ng}$ of genomic DNA, 10x PCR buffer $(20 \mathrm{mM}$ Tris-HCl pH 8.4, 50 mM KCl; Qiagen), 2 mM of dNTPs, 50 ng of each primer, and $1 \mathrm{U}$ Ampli Taq gold DNA polymerase (Applied Biosystems) on a PTC 200 cycler (Peltier Thermal cycler Watertown, Massachusetts, USA). Thermal cycling parameters were initial denaturation at $94^{\circ} \mathrm{C}$ for $2 \mathrm{~min}$, followed by 35 cycles of $30 \mathrm{sec}$ at $94^{\circ} \mathrm{C}$ denaturation, $30 \mathrm{sec}$ at $52^{\circ} \mathrm{C}$ annealing temperature, and $45 \mathrm{sec}$ at $72^{\circ} \mathrm{C}$ extension, followed by a final extension of $5 \mathrm{~min}$ at $72^{\circ} \mathrm{C}$. Thermal cycling parameters remained the same as in the first PCR round except for the number of cycles that is increased to 40 cycles of amplification. Each PCR product $(5 \mu \mathrm{L})$ was analysed by electrophoresis in $2 \%$ agarose gels. A positive control (HBV plasmid DNA) and a negative control of the master mix only were integrated to each run to validate the PCR products that yielded a $340 \mathrm{bp}$ fragment.

\section{Quantification of HBV DNA}

Quantification of HBV DNA was performed with quantitative real-time PCR using a previously described procedure [7] in a GeneAmp 7300 sequence analyzer (Applied Biosystems, Perkin-Elmer, Foster City, CA). HBV-plasmid DNA was used to generate a standard curve following a serial 10 -fold dilution.

\section{Statistical Analysis}

Mean age and all the numerical data were analysed using Student's $t$-test. The chi-square test and Fisher's exact test were used to compare categorical data. For the purpose of our study, $P$ value $\leq 0.05$ was considered statistically significant.

\section{Results}

The demographic, biochemical, and virological parameters of the study group are summarized in Table 1 . The mean age was 35 (range: $3-67$ ) years. The majority (45\%) had multiple sexual partners and $25 \%$ of the subjects had a history of concomitant alcohol use. HCV coinfection was found in 2/96 (2.1\%). Overall, 29/96 (29.2\%) of patients were reactive for anti-HBc, an indication of prior exposure to HBV DNA, and majority $6 / 8$ (75\%) of the patients were female (Table 2). Thus, in the total study population, $21 / 188$ (11.2\%) of patients were identified as OBI and $62.5 \%$ of the OBI patients had CD4 count less than 200 cells $/ \mathrm{mm}^{3}$. Averagely the HBV viral load was $<50$ copies/mL in the OBI samples examined by quantitative PCR.

Serum levels of AST and ALT were higher among patients with $\mathrm{OBI}$ in comparison to anti-HBc positive HBV DNA negative individuals, but the difference failed to reach standard significance $(P=0.13$ and $P=0.07)$, respectively. The comparison of different demographic, biochemical, and virological factors between HBV DNA positive and negative cases was illustrated in Table 3. The distribution of the study participants as per the 1993 Revised Classification System for HIV Infection and Expanded Surveillance Case Definition for AIDS among Adolescents and Adults was as shown in Table 4 . Figure 1 shows the $0.7 \%$ agarose gel picture showing a 340 base pairs amplicon.

\section{Discussion}

The present study represents a comprehensive cross-sectional analysis of prevalence of OBI in an ART naïve HIV positive cohort comprising various risk groups. Most previous studies looking at the clinical effects of OBI in HIV include a large number of patients on anti-HBV drugs as a component of 
TABLE 1: Evaluation of overall demographic, biochemical, and virological parameters of the study populations. $P$ values by $t$-test.

\begin{tabular}{|c|c|c|c|c|}
\hline \multirow{2}{*}{$\begin{array}{l}\text { Characteristic } \\
\text { under analysis }\end{array}$} & \multirow{2}{*}{$\begin{array}{l}\text { Overall status in the } \\
\text { study population }\end{array}$} & \multicolumn{3}{|c|}{ Anti-HBc status in the study population $(n=96)$} \\
\hline & & $\begin{array}{c}\text { Positive } \\
n=28(29.2 \%)\end{array}$ & $\begin{array}{c}\text { Negative } \\
n=68(70.8 \%)\end{array}$ & $P$ value \\
\hline Male & $48(50 \%)$ & $18(64.3 \%)$ & $30(44.1 \%)$ & 0.05 \\
\hline Female & $48(50 \%)$ & $10(35.7 \%)$ & $38(55.9 \%)$ & 0.05 \\
\hline Mean age (range) & $35(3-67)$ & $34(19-67)$ & $34(3-55)$ & 0.009 \\
\hline Alcohol addiction & $24(25 \%)$ & $17(60.7 \%)$ & $34(50 \%)$ & 0.41 \\
\hline Sexual promiscuity & $45(50 \%)$ & $11(39.3 \%)$ & $14(20.6 \%)$ & 0.70 \\
\hline CD $4<200$ cells $/ \mathrm{mm}^{3}$ & $23(25 \%)$ & $13(46.1 \%)$ & $14(20.6 \%)$ & 0.02 \\
\hline $\mathrm{ALT}>40 \mathrm{IU} / \mathrm{L}$ & $27(28.1 \%)$ & $12(42.3 \%)$ & $15(22.1 \%)$ & 0.11 \\
\hline AST $>30 \mathrm{IU} / \mathrm{L}$ & $46(50 \%)$ & $17(60.7 \%)$ & $34(50 \%)$ & 0.14 \\
\hline Anti-HCV positive & $2(2.1 \%)$ & $1(3.8 \%)$ & $1(1.4 \%)$ & 0.24 \\
\hline Anti-HBs positive & $9(9.4 \%)$ & $9(32.1 \%)$ & $2(2.9 \%)$ & 0.0001 \\
\hline
\end{tabular}

TABLE 2: Evaluation of overall demographic, biochemical, and virological parameters of anti-HBc positive samples. $P$ values calculated by Fisher test and $t$-test.

\begin{tabular}{|c|c|c|c|}
\hline \multirow{2}{*}{ Characteristic } & \multicolumn{3}{|c|}{ OBI (anti-HBcAg +ve) $(n 8 / 28)$} \\
\hline & $\begin{array}{c}\text { HBV DNA +ve }(n=8) \\
\text { Anti-HBc +ve }\end{array}$ & $\begin{array}{c}\text { HBV DNA -ve }(n=20) \\
\text { Anti-HBc +ve }\end{array}$ & $P$ value \\
\hline Male & $2(25 \%)$ & $6(30 \%)$ & 0.47 \\
\hline Female & $6(75 \%)$ & $14(70 \%)$ & 0.47 \\
\hline Mean age (range) & $34.5(12-67)$ & $34(3-55)$ & 0.48 \\
\hline Alcohol addiction & $3(34.5 \%)$ & $6(30 \%)$ & 1.00 \\
\hline Sexual promiscuity & $3(37.5 \%)$ & $13(65 \%)$ & 0.15 \\
\hline CD $4<200$ cells $/ \mathrm{mm}^{3}$ & $5(62.5 \%)$ & $7(23.3 \%)$ & 0.47 \\
\hline $\mathrm{ALT}>40 \mathrm{IU} / \mathrm{L}$ & $6(75 \%)$ & $8(26.7 \%)$ & 0.13 \\
\hline $\mathrm{AST}>30 \mathrm{IU} / \mathrm{L}$ & $7(87.5 \%)$ & $12(60 \%)$ & 0.07 \\
\hline Anti-HCV positive & $1(1.3 \%)$ & $1(5 \%)$ & 0.53 \\
\hline
\end{tabular}

TABLE 3: Comparison of different demographic, biochemical, and virological factors between HBV DNA positive and HBV DNA negative.

\begin{tabular}{lcc}
\hline Characteristics & HBV DNA negative $(n=167)$ & HBV DNA positive $(n=27)$ \\
\hline Male & $48(28.7 \%)$ & $7(26 \%)$ \\
Female & $119(71.3 \%)$ & $14(51.2 \%)$ \\
Mean age (range) & $35(12-67)$ & $34(3-55)$ \\
Alcohol addiction & $41(24.6 \%)$ & $11(40.7 \%)$ \\
Sexual promiscuity & $50(30 \%)$ & $21(77.8 \%)$ \\
CD4 (mean) & 410 & 215 \\
ALT $>40$ IU/L & $41.2 \%$ & $58 \%$ \\
AST $>30$ IU/L & $39.8 \%$ & $72.6 \%$ \\
\hline
\end{tabular}

TABLE 4: The distribution of the Human Immunodeficiency Virus (HIV) infected in study participants as per Centers for Disease Control classification for HIV-infected adults and adolescents with the mean CD4 lymphocyte count in each category (WHO, 2009).

\begin{tabular}{lccc}
\hline Category & & No of patients & Mean $\mathrm{CD}_{4}$ count $\left(\mathrm{per} \mathrm{mm}^{3}\right)$ \\
\hline 1 & T cells $>500$ cells $/ \mathrm{mm}^{3}$ & 69 & 506 \\
2 & T cell $200-499$ cells $/ \mathrm{mm}^{3}$ & 81 & 354 \\
3 & T cells $<200$ cells $/ \mathrm{mm}^{3}$ & 38 & 143 \\
\hline
\end{tabular}




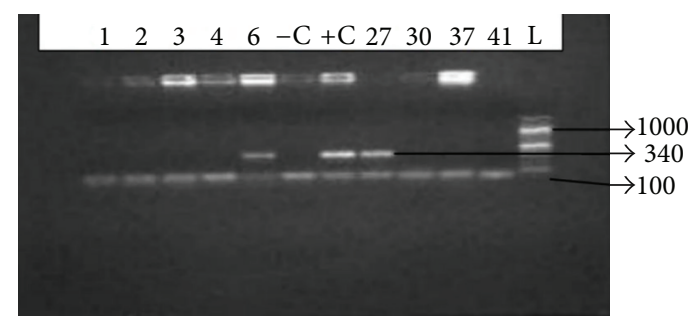

FIgURE 1: PCR for detection of HBV DNA in HBsAg negative patients. Representative agarose gel electrophoresis of PCR products. Lanes 6 and 27 were positive for HBVDNA. Lanes 1, 2, 3, 4, 37, and 42 were negative for HBVDNA. +C: positive control, $-\mathrm{C}$ : negative control, and L: molecular weight size marker.

ART. This study describes the risk factors associated with OBI, frequently of anti-HBc positivity and its possible values as a serological marker for identifying HIV-infected patients who benefit from HBV DNA assay. We found the prevalence of occult $\mathrm{HBV}$ to be $11.2 \%$ among a random selected group of $\mathrm{HIV}$-infected patients. The prevalence of OBI in HIV positive individuals varies worldwide between 0 and $90 \%$, depending on the geographic regions, risk factors, and the exposure involved [6].

In the present study, the prevalence of anti-HBc (29.2\%; 28 of 96$)$ and OBI (28.6\%; 8 of 28) among the ART naive HIV positive cohort was higher compared to previous report on blood donors from studies done in areas of India, areas which reported $21.3 \%$ OBI among the HBsAg negative anti-HBe positive donors [8]. Within Nigeria, HBV and $\mathrm{HCV}$ coinfection among $\mathrm{HCV}$-infected patients have been reported sporadically from different regions [9]. Most of the previous studies on $\mathrm{HBV} / \mathrm{HIV}$ co-infection are aimed at detecting HBV prevalence in the HIV population are based on HBsAg positivity (prevalence 9.9 to $11 \%$ ), but reports on $\mathrm{OBI}$ are scarce. A previous study on intravenous drug users in northeastern India detected a prevalence of $15.9 \%$.

Among the OBI cases, the rate of anti-HBs was lower $(2 / 8 ; 25 \%)$, which may be due to the fact that HIV-infected patients are prone to lose anti-HBs immunity at a higher frequency than the general population [10]. Previous reports suggested that the lower HBV replication was associated with milder hepatic damage [11]. Among the subjects with OBI, elevated ALT or AST was found among 75\% (6 of 8) and not significant. However, our study is cross-sectional; therefore evaluation of long term clinical significance of OBI should be better addressed by follow-up studies.

The low level of viral load obtained in this study buttress the findings in another study that showed that showed that almost all OBI cases are infected with replication incompetent $\mathrm{HBV}$, revealing a strong suppression of overall replication activity and gene expression, thereby resulting in a significant reduced viral load [12].

HIV patients are screened for concomitant chronic hepatitis B using HBsAg ELISA, and it is not considered costeffective to perform HBV DNA testing for all HIV patients in our resource-poor setting. Our study tried to identify possible clinical and serological markers which could guide
DNA testing in these patients. OBI is reported to be common among HCV infection, but we found its prevalence to be low among our study group. However, anti-HCV was not tested among the other HIV positive samples attending the Specialist Hospital, Ikole, Ekiti State, Nigeria. Furthermore, none of the risk factors were found to be statistically significant markers of OBI and cannot be used as an independent marker for identifying patients who should benefit from HBV DNA estimation.

However, as one third of the anti-HBc positive negative patients were positive for HBV DNA (8 of 28), it is recommended that $\mathrm{HIV}$ positive patients with $\mathrm{HBsAg}$ negative/anti-HBc positive patterns should be tested for the presence of HBV DNA irrespective of their anti-HBs status. Nevirapine is commonly included in the first line ART regimens at most treatment centers in Nigeria. Our study identified only 21 subjects with OBI, and all the samples were collected from a single center indicating that results might differ in setting with significant different demographic characteristics. Thus in future multicenter study involving large sample size should be taken up.

\section{Conclusion}

A main implication of the presently viable data is therefore further emphasizing the need for efficient HBV vaccination programs. Overall, the present study highlights the need for screening HBV before the initiation of any HAART containing anti-HBV regimens in $\mathrm{HBV} / \mathrm{HIV}$ coinfected patients. It necessitates the use of NAT for effective laboratory diagnosis of occult HBV infections in HIV positive patients, especially in developing countries where these assays are not widely available.

\section{Conflict of Interests}

The authors declare that there is no conflict of interests regarding the publication of this paper.

\section{References}

[1] M. Torbenson and D. L. Thomas, "Occult hepatitis B," The Lancet Infectious Diseases, vol. 2, no. 8, pp. 479-486, 2002.

[2] C. Bréchot, V. Thiers, D. Kremsdorf, B. Nalpas, S. Pol, and P. Paterlini-Bréchot, "Persistent hepatitis B virus infection in subjects without hepatitis B surface antigen: clinically significant or purely 'occult'?" Hepatology, vol. 34, no. 1, pp. 194-203, 2001.

[3] M. T. Perez-Rodriquez, B. Sopenia, M. Crespo et al., "Clinical significance of "anti-HBc alone" in human immunodeficiency virus positive patients," World Journal of Gastroenterology, vol. 15, no. 10, pp. 1237-1241, 2009.

[4] C. L. Thio, "Hepatitis B in the human immunodeficiency virusinfected patient: epidemiology, natural history, and treatment," Seminars in Liver Disease, vol. 23, no. 2, pp. 125-136, 2003.

[5] N. J. Shire, S. D. Rouster, N. Rajicic, and K. E. Sherman, "Occult hepatitis B in HIV-infected patients," Journal of Acquired Immune Deficiency Syndromes, vol. 36, no. 3, pp. 869-875, 2004.

[6] M. Nunez, P. Rios, M. Perez-Olmeda, and V. Soriano, "Lack of "occult" hepatitis B virus infection in HIV-infected patients," 
Agency for International Development, vol. 16, no. 15, pp. 20992101, 2002.

[7] P. Bhattacharya, P. K. Chandra, S. Datta et al., "Significant increase in HBV, HCV, HIV and syphilis infections among blood donors in West Bengal, Eastern India 2004-2005: exploratory screening reveals high frequency of occult HBV infection," World Journal of Gastroenterology, vol. 13, no. 27, pp. 3730-3733, 2007.

[8] N. Kumarasamy, S. Solomon, T. P. Flanigan, R. Hemalatha, S. P. Thyagarajan, and K. H. Mayer, "Natural history of human immunodeficiency virus disease in southern India," Clinical Infectious Diseases, vol. 36, no. 1, pp. 79-85, 2003.

[9] S. S. Solomon, A. K. Srikrishnan, S. H. Mehta et al., "High prevalence of HIV, HIV/hepatitis $\mathrm{C}$ virus coinfection, and risk behaviors among injection drug users in Chennai, India: a cause for concern," Journal of Acquired Immune Deficiency Syndromes, vol. 49, no. 3, pp. 327-332, 2008.

[10] L. Piroth, C. Binquet, M. Vergne et al., "The evolution of hepatitis $B$ virus serological patterns and the clinical relevance of isolated antibodies to hepatitis B core antigen in HIV infected patients," Journal of Hepatology, vol. 36, no. 5, pp. 681-686, 2002.

[11] A. Knöll, A. Hartmann, H. Hamoshi, K. Weislmaier, and W. Jilg, "Serological pattern "anti-HBc alone": characterization of 552 individuals and clinical significance," World Journal of Gastroenterology, vol. 12, no. 8, pp. 1255-1260, 2006.

[12] G. Raimondo, J.-P. Allain, M. R. Brunetto et al., "Statements from the Taormina expert meeting on occult hepatitis B virus infection," Journal of Hepatology, vol. 49, no. 4, pp. 652-657, 2008. 


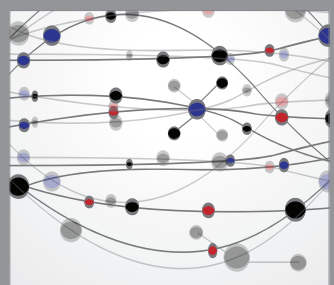

The Scientific World Journal
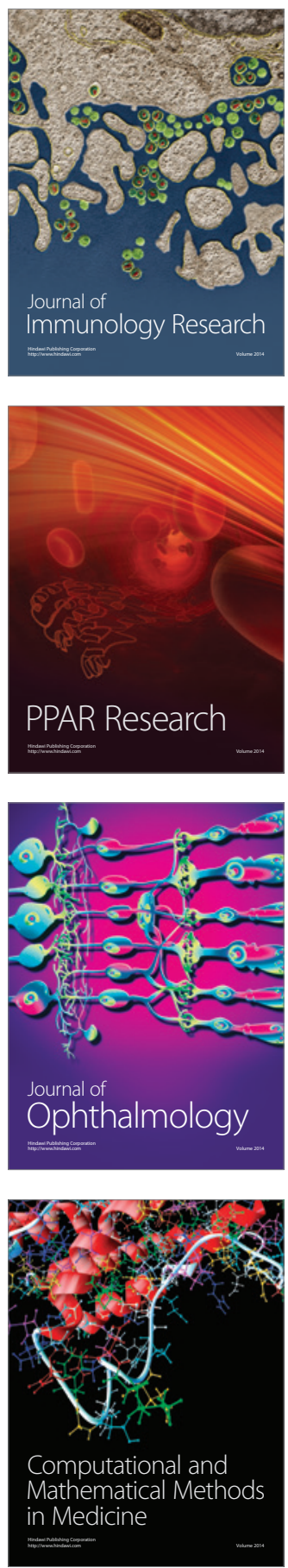

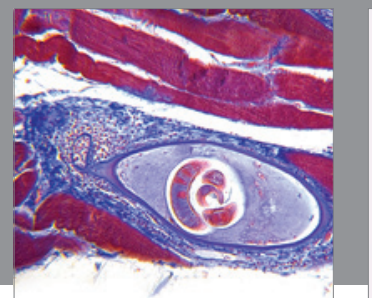

Gastroenterology

Research and Practice
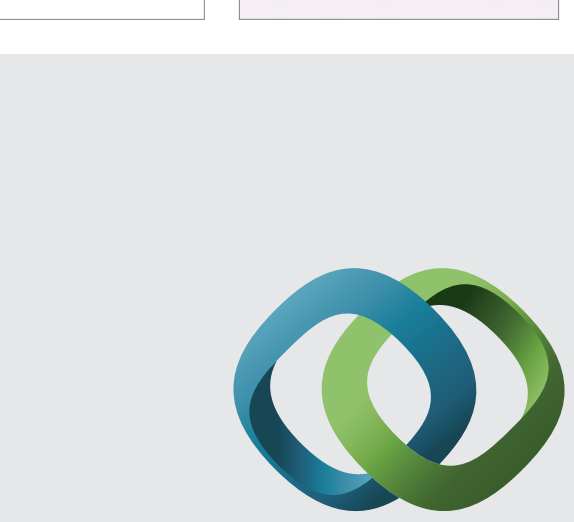

\section{Hindawi}

Submit your manuscripts at

http://www.hindawi.com
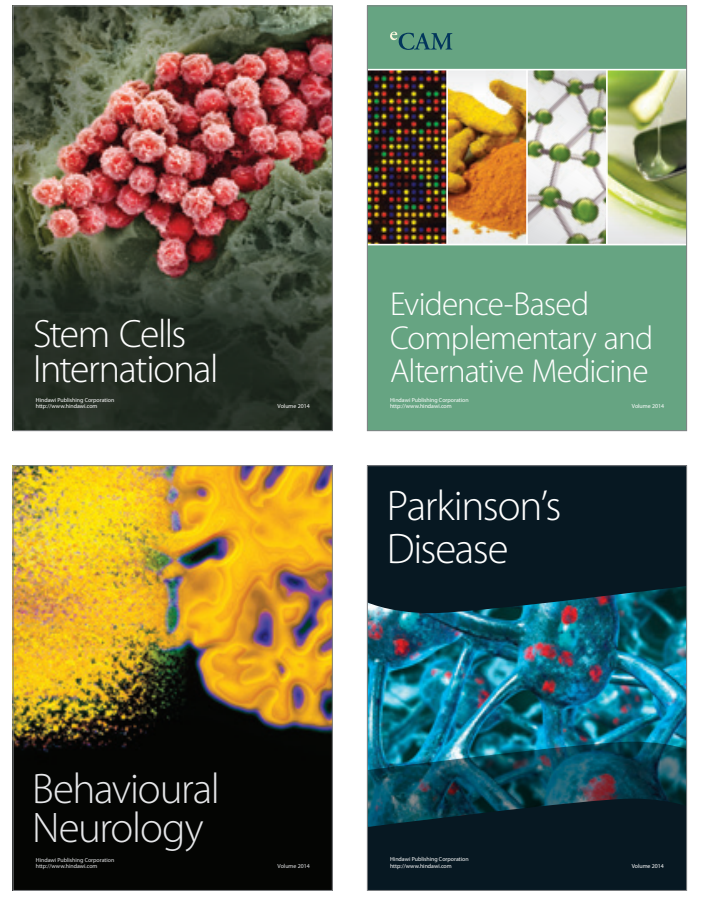
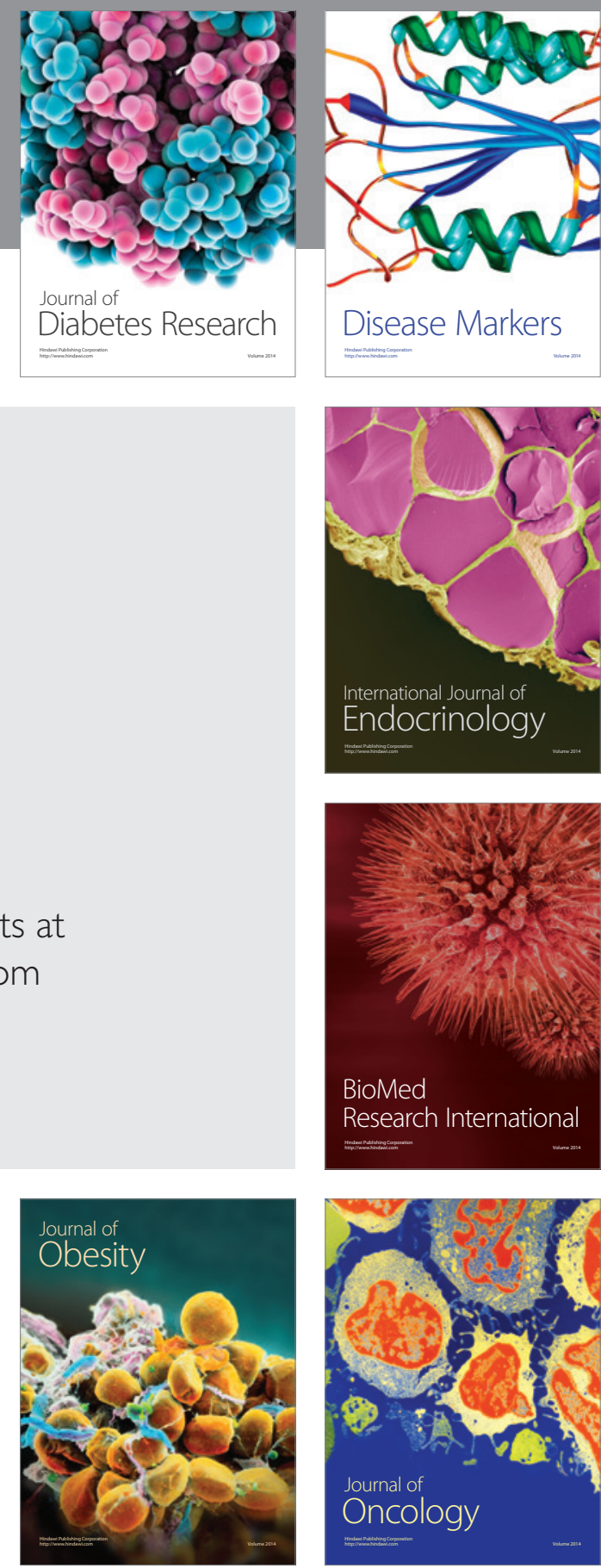

Disease Markers
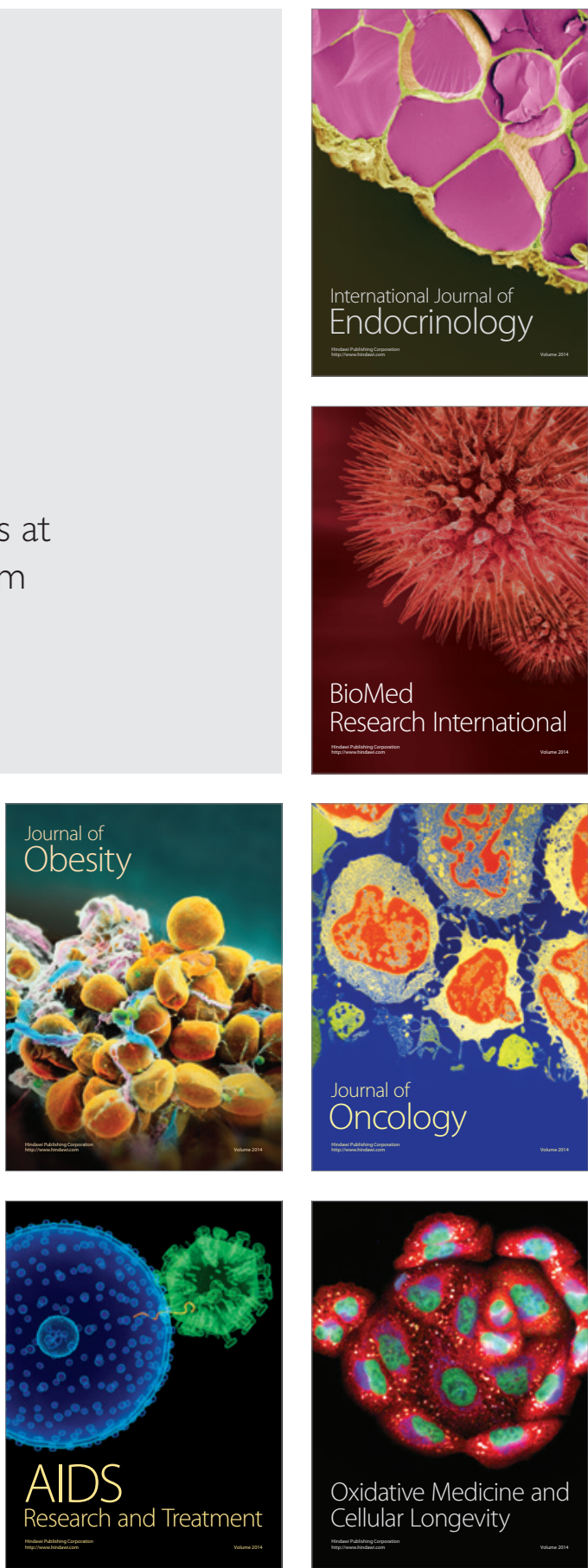